\title{
NILAI JASA FAUNA SEBAGAI KOMPONEN EKOSISTEM DI TAMAN NASIONAL BALURAN
}

Value of Fauna Services as Component Ecosystem in Baluran National Park

Joko Mulyo Ichtiarso

Staf Taman Nasional Baluran, Jawa Timur

Diterima 8 April 2020/Disetujui 12 April 2020

\begin{abstract}
The benefit of ecosystem services are the completeness of the outputs resulting from biological, physical, chemical, and socio-cultural processes in the forest that are useful for human life and environment. The object of research is to know how much the economic value of fauna in ecosystem services which has been utilized by the community buffer village and the dependence on Baluran National Park (BNP). Method of research by quantitative and qualitative analysis. Data collected are typological conditions of BNP community buffer village, human resources who used the services of BNP ecosystem services, identity of community who used ecosystem services, types of ecosystem services used by community, harvest season, location of ecosystem services, community income that uses ecosystem and dependence on $B N P$ ecosystem services. The result of research are economic value of the services of fauna that ecosystem components of BNP that have been used by buffer community village and dependence on BNP have form of forest honey (Rp. 1,073,332,000), kroto (Rp. 784,665,000), and snails (Rp. 648,080). Total economic value of fauna that ecosystem component of BNP is Rp. 2,506,077,000,- per year.
\end{abstract}

Keywords: Fauna, Ecosystem services, Baluran National Park

\section{PENDAHULUAN}

Taman Nasional Baluran (TNB) merupakan salah satu dari 5 (lima) taman nasional pertama yang ditunjuk dan diresmikan oleh pemerintah Indonesia pada tanggal 6 Maret 1980 melalui Surat Keputusan Menteri Pertanian pada tanggal 6 Maret 1980. TNB memiliki jasa ekosistem berupa HHBK sebanyak 10 jenis yang telah dimanfaatkan oleh masyarakat desa penyangga (TN Baluran, 2014). Salah satu komponen ekosistem berupa HHBK yang dapat dimanfaatkan yaitu dari fauna.

Keberadaan HHBK ini membuat masyarakat seakan tidak mempedulikan informasi dan peraturan yang ada di TN Baluran terkait pemanfaatan jasa ekosistem ini. Pengambilan HHBK yang seharusnya hanya di zona pemanfaatan dan 
tradisional atau pemanfaatan khusus saja, pada kenyataanya sudah terlampau masuk ke semua zona bahkan di zona inti. Padahal kegiatan pemanfaatan jasa ekosistem yang di dalamnya termasuk HHBK di kawasan taman nasional hanya diperbolehkan di zona pemanfaatan, tradisional dan khusus, sementara zona inti dan rimba mutlak tidak diizinkan (Kemenhut, 2006).

Tekanan-tekanan dari aktivitas masyarakat ini merupakan cerminan bahwa kondisi social ekonpmi masyarakat di sekitar taman nasional relative rendah sehingga menjadi factor pendorong yang kuat dan dapat mengancam kelestarian sumber daya alam di taman nasional (Alikodra, 1989). Faisal dan Siti (2000) menambahkan bahwa kondisi tersebut dapat menyebabkan suatu potensi konflik. Konflik yang terjadi adanya tumpang tindih kepentingan antara pihak pengelola yang ingin menjaga kelestarian ekosistem dengan masyarakat yang ingin memenuhi kebutuhan ekonominya (Munggoro 1990; Hadimulyo, 1997; Priutt dan Rubin 2009; Ekayani et al., 2014).

Menurut Suhendang (2013) menyatakan bahwa manfaat ekosistem hutan merupakan segala bentuk sumbangan dari keluaran yang dihasilkan akibat proses biologis, fisika, kimiawi, dan sosial budaya di dalam hutan yang berguna bagi kehidupan manusia dan lingkungannya. Masyarakat sekitar Taman Nasional Baluran (TNB) belum sepenuhnya memanfaatkan nilai jasa ekosistem tersebut, padahal terdapat beberapa jenis jasa yang dapat dimanfaatkan oleh masyarakat. Jenis jasa ekosistem yang dapat dimanfaatkan diantaranya hasil hutan bukan kayu (HHBK), rekreasi, dan siklus nutrient (ketersediaan karbon).

Ngakan (2006) menyatakan bahwa HHBK merupakan sumberdaya yang paling bernilai bagi masyarakat sekitar hutan dan (Dewi et al., (2017) menambahkan bahwa HHBK dapat memberikan manfaat secara ekonomi masyarakat di sekitar taman nasional. Manfaat secara ekonomi ini seharusnya dapat meminimalisisr konflik karena secara langsung masyarakat dapat mengambil jasa lingkungan dari taman nasional berupa HHBK dari fauna yang ada di dalam TNB.

Penghitungan nilai ekonomi dari jasa ekosistem menjadi hal yang sangat penting untuk mengetahui seberapa besar manfaat secara ekonomi dari sumber daya alam bagi kelangsungan hidup manusia (Fauzi, 2016). Masyarakat sekitar TNB masih ada yang menggantungkan hidup mereka dari sumberdaya / jasa ekosistem di TNB. Kurang lebih $5 \%$ dari total jumlah penduduk di desa penyangga TNB masih tergantung pada jasa ekosistem di TNB (Balai TNB, 2017). Atas dasar inilah maka dirasa sangat penting untuk mengetahui berapa besar nilai ekonomi dari jasa ekosistem khususnya dari komponen ekosistem berupa fauna yang ada di TNB yang telah dimanfaatkan oleh masyarakat desa penyangga dan tingkat ketergantungan masyarakat terhadap TNB. 


\section{METODE PENELITIAN}

Penelitian dilakukan di semua pintu masuk kawasan TNB yang jumlahnya 12 pintu yang tersebar di 5 desa penyangga TNB, yaitu Desa Sumberanyar, Desa Sumberwaru, Desa Wonorejo, Desa Watukebo, dan Desa Bajulmati. Penelitian dilakukan pada bulan Januari hingga Februari 2019.

Penelitian ini menggunakan pendekatan kuantitatif dan kualitatif. Data yang dikumpulkan meliputi kondisi tipologi masyarakat desa penyangga TNB, sumber daya manusia (SDM) yang memanfaatkan jasa komponen ekosistem fauna TNB, data karakteristik responden masyarakat pemanfaat jasa ekosistem, jenis dan jasa ekosistem fauna yang dimanfaatkan oleh masyarakat (HHBK), data musim pengambilan atau pemungutan, lokasi pemungutan HHBK, pendapatan masyarakat pemanfaat jasa ekosistem dan tingkat ketergantungan masyarakat terhadap jasa ekosistem TNB, sumber daya finansial (mata pencaharian, pendapatan dan pengeluaran masyarakat).

Data dikumpulkan melalui studi dokumen, wawancara mendalam (in depth interview) yaitu proses memperoleh keterangan atau informasi secara detail sesuai tujuan penelitian melalui tanya jawab secara langsung dengan narasumber atau informan (Sugiyono 2009), dan pengamatan terlibat. Pemberian kuisioner dan wawancara mendalam dilakukan kepada masing-masing pemanfaat jasa ekosistem dan 5 kepala desa penyangga. Pemilihan responden dan informan dilakukan secara purposive sampling. Pemilihan informan kunci menggunakan purposive sampling Altinay dan Paraskevas (2008) disesuaikan dengan pengetahuan dan pengalaman informan kunci sesuai masalah yang akan dikaji, dan informan kunci dianggap dapat menjawab tujuan penelitian.

Data jenis jasa ekosistem kemudian dihitung besarnya nilai secara ekonomi menggunakan beberapa pendekatan analisis data. Nilai ekonomi jasa ekosistem berupa HHBK dan jasa wisata dihitung dengan pendekatan harga pasar (market based approach) dengan rumus sebagai berikut:

$$
\mathrm{Bv}=\mathrm{P} \times \mathrm{V} \times \mathrm{I} \times \mathrm{N}
$$

Keterangan :

$\mathrm{Bv}=$ nilai manfaat jasa ekosistem yang dimanfaatkan (Rp/tahun)

$\mathrm{P}=$ rata-rata harga pasar

$\mathrm{V}=$ volume rata-rata jasa ekosistem per satu kali pengambilan

$\mathrm{I}=$ intensitas pengambilan SDAH dalam satu tahun

$\mathrm{N}=$ jumlah pemanfaat/pengambil SDAH. 
Untuk menganalisa tingkat ketergantungan masyarakat terhadap jasa ekosistem TNB digunakan pendekatan rumus Hufschmidt et al. (1987), yaitu:

$$
\mathrm{Kr}=(\mathrm{Ph} / \Sigma \mathrm{P}) \times 100 \%
$$

Keterangan ;

$\mathrm{Kr}=$ tingkat ketergantungan relative $(\%)$

$\mathrm{Ph}=$ pendapatan dari manfaat jasa ekosistem TNB (Rp/tahun)

$\Sigma \mathrm{P}=$ pendapatan total (pendapatan dari manfaat jasa ekosistem $\mathrm{TNB}+$ pendapatan di luar manfaat jasa ekosistem TNB) (Rp/tahun)

\section{HASIL DAN PEMBAHASAN}

\section{Tipologi Masyarakat Desa Penyangga TNB}

Secara administrasi pemerintahan, TNB masuk ke dalam lima desa, yaitu Desa Wonorejo, Desa Sumberwaru, dan Desa Sumberanyar Kecamatan Banyuputih, Kabupaten Situbondo; serta Desa Bajulmati dan Desa Watukebo di Kecamatan Wongsorejo, Kabupaten Banyuwangi. Posisi TNB dalam konfigurasi desa tersebut secara geografis seperti terlihat pada Gambar 1.

Masyarakat desa penyangga hutan merupakan masyarakat yang secara turun temurun tinggal dan menetap di sekitar atau di dalam kawasan hutan dan mempunyai potensi besar untuk berinteraksi dengan kawasan hutan. Masyarakat desa penyangga TNB sebagian besar adalah suku Jawa dan Madura. Kehidupan sosial sangat kental dengan nuansa agamis dan kultur masyarakat pesantren yang lebih mengedepankan karakter tokoh agama di masyarakatnya. Adapun Pengaruh kedua suku ini dapat dilihat pada acara-acara seperti perkawinan dan khitanan namun, tidak ada kebudayaan khusus yang berkembang di masyarakat.

Masing-masing desa mempunyai kondisi topografi dan luasan wilayah yang berbeda-beda. Sebagian besar masyarakat desa penyangga TNB bermata pencaharian sebagai buruh tani sawah atau ladang, sekitar 50,59\% dari keseluruhan jenis mata pencaharian di masing-masing desa dengan tingkat pendapatan yang sangat rendah yaitu sekitar Rp. 750.000,-/bulan/kapita (BTNB 2013). Gambaran mata pencaharian penduduk desa penyangga TNB seperti terlihat dalam Tabel 4. Masyarakat yang hidup di sekitar kawasan hutan seluruh Indonesia masih tergolong sebagai masyarakat yang berada di bawah garis kemiskinan dengan bermata pencaharian sebagai buruh tani ataupun pekerjaan kasar yang lainnya (Marzuki 2008). 


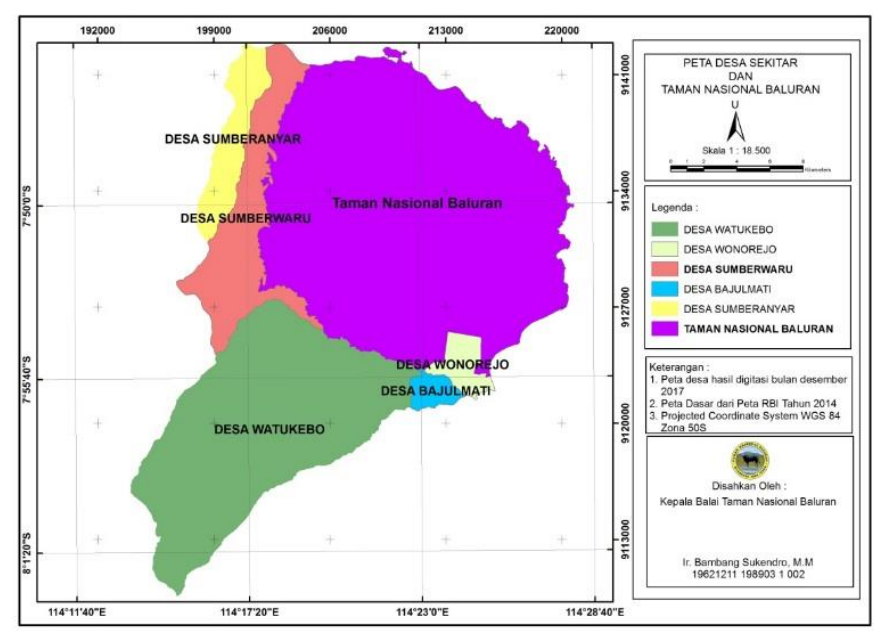

Gambar 1. Geografis desa penyangga TNB

\section{Karakteristik Responden}

Total jumlah responden pemanfaat jasa ekosistem TNB sebanyak 60 orang, terdiri atas 5 (lima) responden per jenis jasa ekosistem dari 12 jenis jasa ekosistem yang dimanfaatkan di TNB. Selain responden, juga dilakukan wawancara mendalam dengan informan yang berasal dari para tokoh masyarakat dan kepala desa di lima desa penyangga TNB. Data dan informasi terkait jasa ekosistem TNB didapat dari responden sedangkan informasi tentang kondisi masyarakat desa penyangga didapat dari para informan.

Responden yang memanfaatkan jasa ekosistem TNB didominasi oleh responden dengan kelas umur yang produktif (umur 25-55 tahun), yaitu sekitar $82 \%$, dan yang paling rendah berada di kelas umur 10-25 tahun, yaitu sebanyak 5\%.

Tingkat pendidikan responden menunjukkan bahwa sebagian besar berpendidikan rendah yaitu tingkat sekolah dasar (SD) sebanyak 35 orang dan hanya sedikit yang berpendidikan menengah atau tinggi yaitu 4 orang. Banyak faktor yang menyebabkan masyarakat atau responden berpendidikan rendah, diantaranya: keterbatasan perekonomian keluarga, minimnya informasi tentang sekolah yang lebih baik, dan kurangnya kesadaran orang tua dan pribadi masingmasing untuk melanjutkan ke jenjang pendidikan yang lebih tinggi.

Jenis kelamin responden adalah laki-laki sebanyak 55 orang $(91,67 \%)$ dan perempuan 5 orang $(8,33 \%)$. Hal ini menunjukkan bahwa masyarakat pemanfaat jasa ekosistem TNB yang berupa HHBK nya bukan hanya laki-laki, tetapi juga perempuan. Ibu rumah tangga yang tidak mempunyai mata pencaharian tetap untuk memenuhi kebutuhan keluarganya biasa masuk ke dalam hutan untuk memungut HHBK dan menjualnya kepada pengepul untuk mendapatkan uang. 


\section{Jenis Jasa Ekosistem TNB}

Constanza et al. (1997) menyebutkan 16 (enam belas) jenis jasa ekosistem, yaitu pengatur udara, pengatur iklim mikro, pengatur gangguan bencana, pengatur tata air, penjaga ketersediaan air, penjaga erosi, siklus nutrient, pembentukan lapisan tanah, pengolah limbah, polinasi, pengontrol biologis, produksi pangan, bahan baku, rekreasi, sumber daya genetik, dan budaya. Jasa ekosistem yang telah dimanfaatkan oleh masyarakat di sekitar TNB secara langsung dan tidak langsung berupa Hasil Hutan Bukan Kayu (HHBK), dampak rekreasi atau wisata dan cadangan karbon (carbon stock). HHBK yang dimanfaatkan sebagian besar diperjual belikan oleh masyarakat desa untuk mendapatkan uang secara terus menerus, hanya sebagian kecil saja yang dikonsumsi pribadi dan keluarga.

Terdapat beberapa 3 jenis HHBK berupa fauna di TNB yang dimanfaatkan oleh masyarakat desa sekitar TNB, yaitu lebah (diambil madu), kroto,dan bekicot. Masing-masing jenis HHBK tersebut tersebar hampir di seluruh wilayah hutan TN Baluran mulai dari zona pemanfaatan hingga zona inti taman nasional. HHBK yang dimanfaatkan oleh masyarakat dipungut dari berbagai lokasi di wilayah hutan TNB tanpa memperhatikan status lokasi pengambilan tersebut dari segi peraturan zonasi taman nasional. Padahal menurut P.76 Tahun 2015 seharusnya aktifitas pemanfaatan HHBK dan yang lainnya hanya diperbolehkan di 3 wilayah zona, yaitu di zona pemanfaatan, zona tradisional, dan di zona khusus.

Masyarakat pemungut HHBK ketika musim panen telah datang, secara berkelompok maupun perorangan akan masuk ke dalam kawasan hutan TNB dan memungut HHBK dengan menggunakan berbagai cara pengambilannya. Masyarakat desa penyangga TNB biasa memungut HHBK dari dalam kawasan TNB sejak tahun 1960-an. Jenis dan lokasi pengambilan HHBK berdasarkan zonasi TNB seperti terlihat dalam Tabel 1.

Tabel 1. Jenis dan lokasi pemungutan HHBK berdasarkan zonasi TNB

\begin{tabular}{|c|c|c|c|c|c|c|c|c|c|}
\hline \multirow{2}{*}{ No } & \multirow{2}{*}{$\begin{array}{c}\text { Jenis HHBK yang } \\
\text { Dimanfaatkan }\end{array}$} & \multirow{2}{*}{$\begin{array}{c}\text { Blok } \\
\text { Pengambilan }\end{array}$} & \multicolumn{7}{|c|}{ Zona TNB } \\
\hline & & & $\mathbf{Z I}$ & $\mathbf{Z R}$ & ZKh & ZRh & $\mathbf{Z P}$ & ZT & $\mathbf{Z P b}$ \\
\hline \multirow[t]{8}{*}{1} & Madu & Amparan & $\sqrt{ }$ & $\sqrt{ }$ & & & $\sqrt{ }$ & & \\
\hline & & Bitakol & & $\sqrt{ }$ & & & & & \\
\hline & & Perengan & & $\sqrt{ }$ & & & & & \\
\hline & & Bama & & & & & $\sqrt{ }$ & & \\
\hline & & Grekan & & $\sqrt{ }$ & & & & & \\
\hline & & Putatan & $\sqrt{ }$ & & & & & & \\
\hline & & Rowo Jambe & & $\sqrt{ }$ & & & & & \\
\hline & & Semiang & $\sqrt{ }$ & & & & & & \\
\hline \multirow[t]{3}{*}{2} & Bekicot & Perengan & $\sqrt{ }$ & $\sqrt{ }$ & & & & & \\
\hline & & Bekol & & $\sqrt{ }$ & & & & & \\
\hline & & Kramat & & $\sqrt{ }$ & & & & & \\
\hline
\end{tabular}




\begin{tabular}{|c|c|c|c|c|c|c|c|c|c|}
\hline \multirow{2}{*}{ No } & \multirow{2}{*}{$\begin{array}{c}\text { Jenis HHBK yang } \\
\text { Dimanfaatkan }\end{array}$} & \multirow{2}{*}{$\begin{array}{c}\text { Blok } \\
\text { Pengambilan }\end{array}$} & \multicolumn{7}{|c|}{ Zona TNB } \\
\hline & & & ZI & ZR & ZKh & ZRh & $\mathbf{Z P}$ & ZT & $\mathbf{Z P b}$ \\
\hline \multirow{8}{*}{3} & & Merak & & $\sqrt{ }$ & & & & & \\
\hline & & Alas malang & & & & $\sqrt{ }$ & & & \\
\hline & & Gunung motor & $\sqrt{ }$ & & & & & & \\
\hline & & Evergreen & $\sqrt{ }$ & & & & & & \\
\hline & Kroto & Evergreen & $\sqrt{ }$ & $\sqrt{ }$ & & $\sqrt{ }$ & & & \\
\hline & & Gatel & & $\sqrt{ }$ & & & & & \\
\hline & & Widuri & $\sqrt{ }$ & & & & & & \\
\hline & Jumlah & 23 & 8 & 11 & - & 2 & 2 & - & - \\
\hline
\end{tabular}

Keterangan : ZI (Zona Inti), ZR (Zona Rimba), ZKh (Zona Khusus), ZRh (Zona Rehabilitasi), ZP (Zona Pemanfaatan), ZT (Zona Tradisional), ZPb (Zona Perlindungan Bahari)

Data dalam Tabel 1 menunjukkan bahwa terdapat sebanyak 23 lokasi pemungutan HHBK dari fauna di TNB. Sebagian besar lokasi tersebut berada di wilayah zona rimba (11 lokasi) dan zona inti (8 lokasi), lokasi lainnya di wilayah zona rehabilitasi sebanyak 2 lokasi dan di wilayah zona pemanfaatan sebanyak 2 lokasi. Artinya, aktiftas pemanfaatan HHBK dari fauna di TNB yang semula legal menjadi tidak legal setelah keluarnya aturan pengelolaan kawasan konservasi, khususnya aturan tentang zonasi taman nasional karena di zona inti dan zona rimba tidak diperbolehkan melakukan kegiatan apapun kecuali dalam konteks penelitian, pendidikan dan kegiatan pengamanan kawasan hutan (P.76 tahun 2015). Hingga saat ini upaya yang dilakukan oleh pengelola TNB masih sebatas pada upaya pengawasan dan antisispasi terhadap kemungkinan kegiatan ikutan dari aktifitas pemungutan HHBK, seperti berburu binatang dan pencurian kayu, belum pada upaya pencegahan apalagi memberhentikan aktifitas pemungutan HHBK di TNB ${ }^{1}$.

Berdasarkan penelitian ini, untuk komoditas HHBK berupa rumput dan kayu bakar pengambilannya atau pemungutannya dilakukan sepanjang tahun, sedangkan HHBK yang lain waktu pemungutannya menyesuaikan dengan kalender musim berbunga atau berbuah tanaman tersebut seperti yang terlihat dalam Tabel 2 .

Tabel 2. Waktu pemungutan HHBK di TNB oleh masyarakat

\begin{tabular}{rllllllllllllll}
\hline \multirow{2}{*}{ No } & \multirow{2}{*}{ Jenis } & \multicolumn{1}{c}{ Waktu (Bulan) Pengambilan } \\
\cline { 3 - 10 } & & 1 & 2 & 3 & 4 & 5 & 6 & 7 & 8 & 9 & 10 & 11 & 12 \\
\hline 2 & Madu & & & & & & & & & & & & \\
8 & Bekicot & & & & & & & & & & & & & \\
9 & Kroto & & & & & & & & & & & & \\
\hline
\end{tabular}

Sumber : data penelitian 2018

\footnotetext{
${ }^{1}$ Kepala Subbagian Tata Usaha Balai TNB
} 


\section{Nilai Jasa Komponen Ekosistem Fauna TNB}

\section{Madu Hutan}

Madu hutan sudah dimanfaatkan oleh masyarakat sekitar TNB sejak tahun 1960-an. Jasa ekosistem ini mempunyai jadwal pemungutan sesuai dengan musim berbunga berbagai macam jenis tanaman, karenanya madu yang dihasilkan akan sangat dipengaruhi oleh jenis dan jumlah bunga dari tanaman hutan tersebut. Pemungutan madu di TNB berlangsung pada bulan Mei hingga November setiap tahunnya. Total jumlah pemungut madu yang ada sebanyak 80 orang dan jumlah pengepul madu sebanyak 4 orang.

Harga jual madu dari pemungut kepada pengepul berkisar Rp.80.000,/botol. Padahal jika dilihat dari perkembangan saat ini harga jual madu dangat tinggi karena dirasa sangat baik untuk menjaga imun tubuh sehingga kisaran di pasaran teruatama di salah satu media online berkisar antara 150.000-250.000/botol (Gambar 2). Hal ini sangat diperlukan harga beli dari pengepul harusnya dapat lebih tinggi atau masyarakat diberikan penyuluhan cara yang baik dalam pengolahan madu dan dijual secara mandiri oleh masyarakat, sehingga keuntungan secara ekonominya lebih tinggi.



a. Madu hutan TNB



b. Madu dalam botol

Gambar 2. Pemanfaatan madu hutan TNB

Pemanfaatan madu hutan terdapat di 10 lokasi di dalam kawasan TNB, yaitu di zona inti (3 lokasi), zona rimba (5 lokasi), dan di zona pemanfaatan terdapat 2 lokasi. Pola pemungutan yang selama ini dilakukan adalah dengan memanjat pohon yang terdapat sarang madu kemudian sarang tersebut dipotong dengan menggunakan pisau. Pola pemanfaatan madu seperti ini masih tergolong sangat memperhatikan keberlanjutan pohon inang tersebut. Selama ini dapat dipastikan 
bahwa tidak ada pemungut madu hutan TNB yang melanggar aturan taman nasional, seperti memburu hewan, membakar hutan, dan menebang pohon ${ }^{2)}$.

\section{Bekicot}

Potensi jasa ekosistem TNB berupa bekicot sudah lama dimanfaatkan oleh masyarakat desa penyangga TNB, khususnya di Desa Wonorejo. Pemanfaatan bekicot dilakukan oleh masyarakat Desa Wonorejo sejak akhir tahun 1990-an dengan jadwal pemungutan pada bulan Februari hingga Mei setiap tahunnya. Populasi bekicot sangat besar ketika musim hujan dan kelembaban di sekitar hutan TNB tinggi. Jumlah pemungut bekicot di Desa Wonorejo sebanyak 40 orang dengan pengepul 1 orang.

Adapun harga jual bekicot pada saat penelitian dilakukan adalah sebesar Rp. 2.000,-/kg. Bekicot TNB dan hasil olahannya dapat dilihat pada Gambar 3. Padahal jika dilihat pada salah satu situs jual beli online bekicot juga dapat dimanfaatkan lendirnya dengan harga Rp185.000/10ml dan per ekor berkisar antara Rp. 2.500 Rp. 4.500 (shopee.co.id). Secara ilmiah, lendir bekicot ini dapat digunakan sebagai penyembuhan luka sayat karena memiliki kandungan glikosaminoglikan yang berperan dalam proses penyembuhan luka (Usman dan Nur, 2015). Selain itu, cangkang bekicot juga dapat dimanfaatkan sebagai kitosan untuk pengawet alami berbagai sayuran (Aisyah et. al., 2015).

Anonim (2009) menyatakan bahwa bekicot dapat dijadikan sumber protein yang telah diekspor ke Perancis pada tahun 1986 mencapai 1.212 ton, sedangkan pada tahun 1990 naik menjadi 11.000 ton. Hal ini sangat diperlukan harga beli dari pengepul harusnya dapat lebih tinggi atau masyarakat diberikan penyuluhan cara yang baik dalam pengolahan bekicot dan dijual secara mandiri oleh masyarakat, sehingga keuntungan secara ekonominya lebih tinggi.

Hasil penelitian ini menunjukkan bahwa pengambilan atau pemungutan bekicot di TNB terjadi di 8 lokasi, yaitu 3 lokasi berada di wilayah zona inti, 4 lokasi berada di wilayah zona rimba, dan 1 lokasi berada di wilayah zona rehabilitasi. Namun demikian, sejak awal tahun 2017 aktifitas pemungutan bekicot di TNB secara total berhenti. Hal ini dikarenakan pengepul tunggal dan yang memasarkan bekicot sudah sadar dan mendapat pekerjaan lain yang lebih layak daripada mencari bekicot di $\mathrm{TNB}^{3}$. Mantan pengepul bekicot ini pun menjadi salah satu contoh masyarakat desa yang tidak lagi menggantungkan dirinya pada jasa ekosistem TNB.

\footnotetext{
2) Kepala Desa Wonorejo Kec.Banyuputih Kab.Situbondo

${ }^{3}$ Kepala Desa Wonorejo, Kecamatan Banyuputih-Situbondo
} 


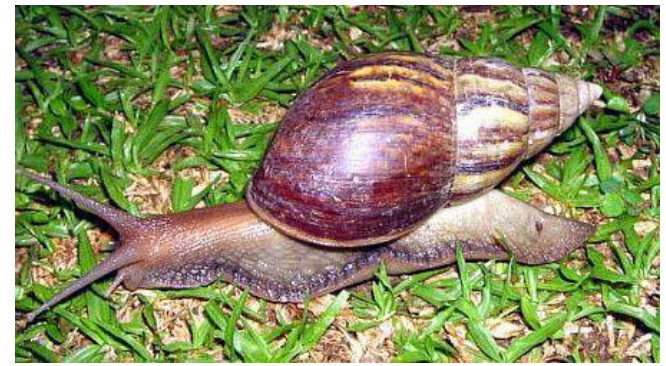

a. Bekicot di TNB

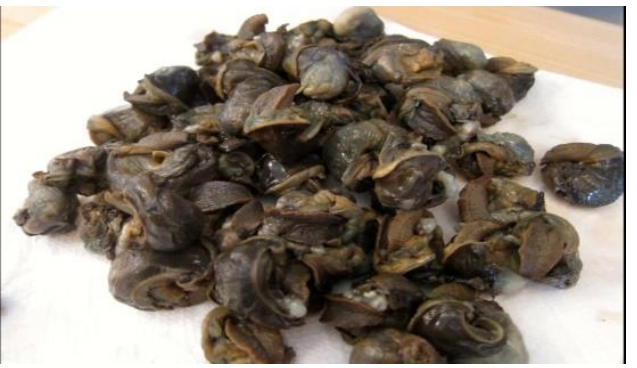

b. Olahan bekicot

Gambar 3. Potensi Bekicot TNB

\section{Kroto}

Potensi jasa ekosistem sebagai pakan burung ini masih cukup melimpah dan dicari oleh banyak orang. Kroto TNB berdasarkan hasil penelitian ini biasanya dipungut oleh masyarakat desa penyangga TNB, khususnya Desa Wonorejo dan Desa Watukebo pada bulan Mei hingga Desember. Jumlah pemungut tercatat sebanyak 15 orang dan tidak ada pengepul. Pemungut kroto TNB setelah mengambil di dalam kawasan TNB langsung menjualnya kepada pedangang atau kios penjual burung-burung berkiacau di Pasar Bajulmati Kecamatan WongsorejoBanyuwangi. Harga jual kroto dari pemungut kepada pedagang pakan burung tersebut pada saat penelitian ini dilakukan yaitu sebesar Rp. 70.000,-/kg. Jasa ekosistem TNB yang berupa kroto dapat dilihat pada Gambar 4.

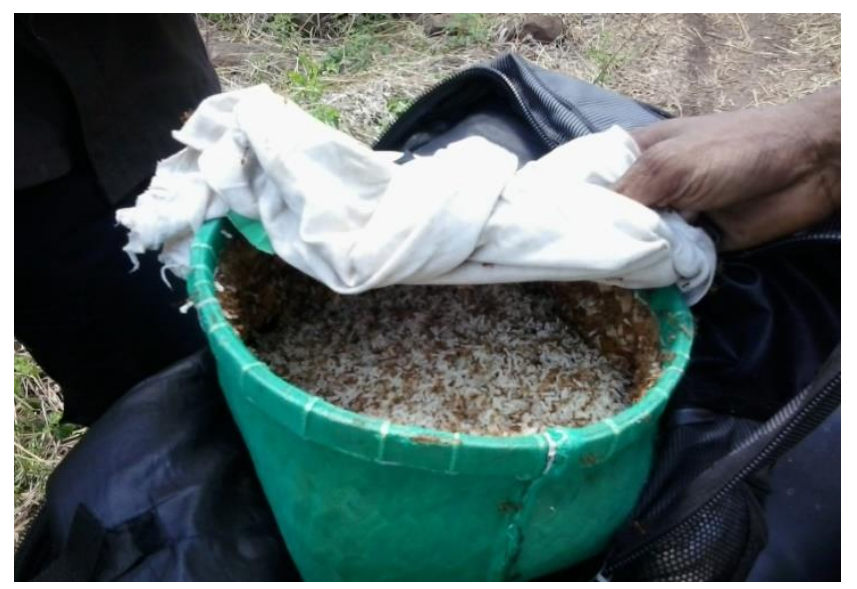

Gambar 4. Pemungutan kroto TNB oleh masyarakat

Berdasarkan penelitian ini ditemukan 4 lokasi pengambilan, yaitu 1 lokasi berada di wilayah zona inti, 2 lokasi berada di wilayah zona rimba, dan 1 lokasi berada di wilayah zona rehabilitasi. Masyarakat pemungut kroto TNB hingga saat ini masih sering masuk ke dalam kawasan hutan seiring jumlah permintaan pakan burung yang terus meningkat. Namun demikian, pemungut kroto tidak selalu mendapatkan kroto setiap kali masuk ke dalam hutan. Selain langka, karena 
keberadaan kroto di dalam hutan sangat sulit untuk dipungut dan cukup berbahaya bagi keselamatan pemungut sehingga pendapatan dari memungut kroto ini pada dasarnya kecil.

Total nilai ekonomi dari jasa lingkungan di TN Baluran adalah penjumlahan dari nilai langsung dan tidak langsung. Adapun jumlah nilai ekonomi tersebut seperti tersaji pada Tabel 2.

Tabel 2. Nilai Jasa komponen ekosistem berupa fauna di TNB

\begin{tabular}{|c|c|c|}
\hline No & Jasa Ekosistem & Nilai Manfaat (Rp/Tahun) \\
\hline 1 & Madu & 1.073 .332 .000 \\
\hline 2 & Kroto & 784.665 .000 \\
\hline 3 & Bekicot & 648.080 .000 \\
\hline \multicolumn{2}{|c|}{ Total Nilai Ekonomi Jasa Fauna TNB 2019} & 2.506.077.000 \\
\hline
\end{tabular}

Total Nilai Ekonomi jasa komponen ekosistem berupa fauna di TNB secara langsung dan tidak langsung adalah sebesar Rp. 2.506.077.000,-- Angka nilai ekonomi jasa lingkungan TN Baluran ini yang dapat atau telah diterima oleh sebagian masyarakat desa penyangga TN Baluran. Namun, masih banyak lagi jasa jasa ekosistem TN Baluran yang belum dilakukan kajian penilaiannya. Seperti jasa flora, air, jasa stok karbon dan jasa lainnya.

\section{SIMPULAN}

Nilai ekonomi dari jasa salah satu komponen ekosistem berupa fauna di dalam kawasan TNB yang telah dimanfaatkan oleh masyarakat desa penyangga dan tingkat ketergantungan masyarakat terhadap TNB berupa madu hutan (1.073.332.000), kroto (784.665.000), dan bekicot (648.080.000) dengan total nilai ekonomi sebesar Rp. 2.506.077.000,--. per tahun.

\section{DAFTAR PUSTAKA}

Altinay L, Paraskevas A. (2008). Planning Research in Hospitality and Tourism. Burlington (US): Butterworth-Heinemann.

Anonim. (2009). Asosiasi Bekicot Indonesia: produk Olahan Bekicot. Retrieved from http://bekicotfansclub.blogspot.com/2009/05/.

Aisyah, N., A. Rofieq, dan P. Wahyono. (2015). Penggunaan Kitosan Cangkang Bekicot (Achantina fulica) untuk Bahan Pengawet Alami Berbagai Jenis Sayuran sebagai Sumber Belajar dalam Perencanaa Pembelajaran Bioteknologi. Jurnal Pendidikan Biologi Indonesia, 1(2), 219-229. 
[Balai TNB] Balai Taman Nasional Baluran. (2014). Identifikasi dan Pemetaan Sebaran HHBK dan Pemanfaatannya oleh Masyarakat di Taman.

Dewi, E.C., Sunarminto T, Arief H. (2017). Nilai Ekonomi Pemanfaatan Sumberdaya Alam Hayati Taman Nasional Baluran oleh Masyarakat Desa Wonorejo Kabupaten Situbondo Jawa Timur. Media Konservasi, 22(3), 277283.

Ekayani, M., Nuva, Yasmin R, Sinaga F, Maaruf LOM. (2014). Wisata alam Taman Nasional Gunung Halimun Salak: solusi kepentingan ekologi dan ekonomi. Jurnal Ilmu Pertanian Indonesia, 19(1), 29- 37

Faisal, H. F. dan Siti H. (2000). Inovasi Penyelesaian Sengketa Pengelolaan Sumberdaya Hutan. Bogor: Pustaka LATIN.

Fauzi, A. (2016). Valuasi Ekonomi Dan Penilaian Kerusakan Sumber Daya Alam Dan Lingkungan. Bogor: IPB Press.

Hadimulyo. (1997). Mempertimbangkan ADR: Kajian Alternatif Penyelesaian Konflik di Luar Peradilan. Jakarta: ELSAM.

Munggoro, DW. (1999). Manajemen Kemitraan: Meretas Kemelut Pengelolaan Kawasan Konservasi dalam Prosiding Seminar Pemberdayaan Aset Perekonomian Rakyat Melalui Strategi Kemitraan Di Kabupaten Jember. Bogor: Pustaka LATIN

Pruit, D.G., Rubin JZ. (2009). Teori Konflik Sosial. Yogyakarta: Pustaka Pelajar.

Sugiyono. (2009). Metode Penelitian Kuantitatif Kualitatif dan RD. Bandung: Alfabeta.

Suhendang, Endang. (2013). Pengantar Ilmu Kehutanan. Bogor: IPB Press.

Usman, A.R. dan Nur A. Salikunna. (2015). Pengaruh Lendir Bekicot (Achatina fulica) terhadap Waktu Penutupan Luka Sayat (Vulnus scissum) pada mencit (Musmulculus). Medika Tadulako (jurnal Ilmiah Kedokteran), 2(1), 31-39. 